\title{
IMMUNE RESPONSES IN LUMPFISH (CYCLOPTERUS LUMPUS L.) LEUKOCYTES UPON BACTERIA CHALLENGE
}

\author{
Gyri T. Haugland, Anita Rønneseth, Håvard Ø. Eggestøl, Harald S. Lunde and Heidrun I. \\ Wergeland $^{\S}$ \\ Department of Biology, University of Bergen, Norway
}

\begin{abstract}
Lumpfish (Cyclopterus lumpus L.) has shown to be an efficient biological tool in the fight against salmon lice (Lepeophtheirus salmonis) and are chosen by many fish farmers in Norway as an alternative to medicinal treatment. However, to improve the fish health and increase the overall efficiency of the cleaner fish strategy, more knowledge about its immune system and protective vaccines are required. We will present the current knowledge of its immune cells and its innate and adaptive immune responses upon bacteria challenge.
\end{abstract}

\section{KEYWORDS}

Lumpfish, cleaner-fish, immune responses, leukocytes, bacteria-challenge

§Corresponding author. Tel.: +47 55584443

E-mail address: Heidrun.Wergeland@uib.no 